\title{
Seasonal variations of cough reflex sensitivity in elite athletes training in cold air environment
}

Julie Turmel' ${ }^{1}$, Valérie Bougault ${ }^{2}$ and Louis-Philippe Boulet ${ }^{1 *}$

\begin{abstract}
Background: Exercise-induced cough is common among athletes. Athletes training in cold air often report an increasingly troublesome cough during the winter season. Chronic airway irritation or inflammation may increase the sensory response of cough receptors. The aim of this study was to evaluate the seasonal variability of cough reflex sensitivity to capsaicin in elite athletes.
\end{abstract}

Methods: Fifty-three elite winter athletes and 33 sedentary subjects completed a respiratory questionnaire and a capsaicin provocation test during the summer, fall, and winter. Allergy skin prick tests, spirometry, eucapnic voluntary hyperpnea test (EVH), methacholine inhalation test (MIT), and induced sputum analysis were also performed.

Results: In athletes, the prevalence of cough immediately after exercise was high, particularly during winter. Athletes often showed a late occurrence of cough between 2-8 $\mathrm{h}$ after exercise. The cough reflex sensitivity to capsaicin was unchanged through the seasons in both athletes and non-athlete subjects. No significant correlations were found in groups between cough reflex sensitivity to capsaicin and the number of years in sport training, the number of hours of training per week, $\mathrm{EVH}$ response (\% fall in $\left.\mathrm{FEV}_{1}\right)$, airway responsiveness to methacholine $\left(\mathrm{PC}_{20}\right)$, airway inflammation or atopy.

Conclusion: The prevalence of cough immediately and a few hours after exercise is high in athletes and more frequently reported during winter. However, cough does not seem to be associated with cough reflex hypersensitivity to capsaicin, bronchoconstriction, or airway inflammation in the majority of athletes.

Keywords: Cough, athletes, cold air

\section{Background}

Cough is widely recognized as a key symptom in the diagnosis of asthma, being frequently related to an upper or lower respiratory tract infection or associated to post nasal drip syndrome and gastro-oesophageal reflux [1]. It may also be due to environmental exposures.

In elite athletes, particularly those training in a coldair environment, exercise-induced cough is a common complaint $[2,3]$. Usually, the inspired air is warmed up to body temperature through heat exchange in the upper airways, before entering into the lungs. However, this mechanism is compromised during exercise in cold

\footnotetext{
* Correspondence: Ipboulet@med.ulaval.ca

${ }^{1}$ Centre de recherche de l'Institut universitaire de cardiologie et de Pneumologie de Québec, 2725 Chemin Ste-Foy, Québec, Qc G1V 4G5, Canada

Full list of author information is available at the end of the article
}

weather because nose breathing switch to mouth breathing. Consequently, the air reaching trachea and bronchi can be as low as $20^{\circ} \mathrm{C}$ due to an insufficient heat exchange $[4,5]$.

The high frequency of exercise-induced respiratory symptoms in winter athletes raises the question whether these symptoms are due to airway dysfunction (hyperresponsiveness) or are normal variant physiologic responses to cold dry air.

In acute or chronic respiratory diseases where cough is a prominent symptom, cough reflex sensitivity is often increased [6,7]. An increase in cough reflex sensitivity could be due to an irritation and/or inflammation of the airways. Such hypersensitivity can lead to an abnormal response to inhaled stimuli such as cold air or pollutants [8]. Airway sensory hyperreactivity (SHR) is defined in those individuals who reported aggravation or

\section{Biomed Central}


triggering of cough in the presence of one or more of the following; change in air temperature, odours and/or during talking, laughing, or singing.

The tussive agent capsaicin is an excellent tool for the measurement of cough reflex sensitivity, being safe, reproducible, and dose-dependent [9]. Cough sensitivity is measured using the threshold concentration that induces a determined number of coughs, which is used as an index of cough sensitivity. However, few studies have reported reference values of cough threshold to inhaled capsaicin. In healthy individuals, $\mathrm{C}_{5}$ (concentration of capsaicin inducing 5 coughs) values between $125-186 \mu \mathrm{M}$ were reported $[10,11]$.

To further investigate the effect of long-term (chronic) repeated inhalation of cold-air on cough sensitivity, we prospectively performed capsaicin cough challenge testing in endurance winter athletes and a group of nonathlete subjects. The aims of this study were to: 1) evaluate the prevalence of exercise-induced cough symptoms; and 2) look at the variability of the cough reflex sensitivity to capsaicin between seasons.

\section{Methods}

Data were collected at the Centre de Recherche de l'Institut universitaire de cardiologie et de pneumologie de Québec (Quebec City, Canada), between 2007 and 2008. Fifty-three elite winter athletes from Canadian national teams and provincial Quebec teams, and 33 non-athlete subjects were recruited. Subjects were aged between 14 and 25 years and were all non-smokers. Non-athletes subjects exercised primarily indoors, less than $3 \mathrm{~h}$ weekly. Subjects were asked not to take inhaled corticosteroids for 4 weeks before the study, short-acting $\beta_{2}$ agonists $8 \mathrm{~h}$ before testing, long-acting $\beta_{2}$-agonists $48 \mathrm{~h}$ before testing, and leukotriene receptor antagonists $72 \mathrm{~h}$ before testing. Subjects had no respiratory infections for at least 3 weeks before their study visits. Written informed consent was obtained from each subject and/ or their parents or guardians before inclusion in the study. The protocol was approved by the local ethics committee.

\section{Study design}

Subjects were evaluated during the summer (June-July), fall (October-November), and winter (February-March) seasons. Each visit was performed at least $12 \mathrm{~h}$ after the last training session for all athletes. During the initial visit, each subject underwent a physical examination and allergy skin-prick tests. During each subsequent visit, a capsaicin provocation test, to assess the cough reflex sensitivity to capsaicin, a spirometry, a Eucapnic Voluntary Hyperpnea (EVH) test, and a methacholine inhalation test (MIT) were performed consecutively. Following EVH, MIT was always performed after recovery of expiratory flows within $10 \%$ of baseline [12]. Induced sputum was then obtained for airway inflammation analysis.

\section{Questionnaire}

The two following questions of the European Community Respiratory Health Survey (ECRHS) [13] were used to evaluate cough symptoms during exercise and in other situations.

1) When you exercise, do you cough?

- During exercise

- Within $1 \mathrm{~h}$ after exercise

- Between 2 and $8 \mathrm{~h}$ after exercise

2) Currently, do you cough in the following situations?

- After you get up in the morning

- During the night

- When you are exposed to tobacco smoke

- When you are exposed to other irritants/strong odors

- When you are exposed to dust

- When you are exposed to tree pollens (spring)

- When you are exposed to grass pollens (summer)

- When you are exposed to ragweed pollens (August, September)

- in the presence of a domestic animal

- During a respiratory tract infection

- Other occasions

\section{Capsaicin provocation test}

Capsaicin challenge was conducted to assess the sensitivity of the cough reflex. The capsaicin solution (Sigma Chemical Co, St-Louis, MO) was prepared from a stock solution of $10 \mathrm{mM}$ which was further diluted with saline to obtain serial doubling concentrations ranging from 0.98 to $1000 \mu \mathrm{M}$. Fresh dilutions were prepared at each day of testing. Aerosol was delivered by single-breath inhalation through a breath-activated nebulizer (DeVilbiss 646, DeVilbiss Health Care Inc., Somerset, PA) controlled by a dosimeter (Coco Digi Doser, Pulmonary data Service Instrumentation Inc., Louiseville, $\mathrm{CO}$ ), at an output of $0.5 \mathrm{~L} / \mathrm{s}$. Three placebo inhalations of normal saline were randomly interspersed between capsaicin doses, with both operator and subject blinded to their positions. Subjects were asked to inhale once deeply over $2 \mathrm{~s}$, at 2 -min intervals. The number of coughs during the first minute after each dose was manually counted by the operator. The challenge ended when the subject coughed five times or more $\left(C_{5}\right)$ or when the maximal dose of capsaicin had been given. In subjects who did not cough, a $C_{5}$ value of $1000 \mu \mathrm{M}$ was 
assumed. Subjects were unaware that the end point of the study was the number of induced coughs [10]. The results of cough challenge testing are most frequently expressed as $\mathrm{C}_{2}$ and $\mathrm{C}_{5}$ values, which are defined as the lowest concentrations generating two or five coughs per inhalation, respectively.

\section{Skin-prick tests}

Skin-prick tests were performed with a battery of 26 common airborne allergens. Normal saline and histamine were used as negative and positive controls, respectively. Skin wheal diameters were recorded at 10 min as the mean of 2 perpendicular measurements. A positive response was defined as a skin wheal diameter $\geq 3 \mathrm{~mm}$.

\section{Spirometry}

Forced expiratory volume in one second $\left(\mathrm{FEV}_{1}\right)$ and forced vital capacity (FVC) were assessed from flowvolume curves performed according to the American Thoracic Society specifications using an American Thoracic Society-approved spirometer [14]. Predicted values were derived from Knudson et al. [15]. The best of three reproducible measurements was used for analysis.

\section{Eucapnic voluntary hyperpnea test (EVH)}

The EVH test was performed according to the method described by Anderson and Brannan [16]. Briefly, subjects inhaled a dry-air mixture containing $5 \% \mathrm{CO}_{2}$, and the balance in air at room temperature, for $6 \mathrm{~min}$. The target ventilation was 30 times the $\mathrm{FEV}_{1}$ according to the baseline $\mathrm{FEV}_{1}$ recorded at each visit. $\mathrm{FEV}_{1}$ was measured before the test and at 3, 5, 10, 15, 20, 25, and 30 min after the EVH test. At each time interval, $\mathrm{FEV}_{1}$ was measured twice and if there was a $>10 \%$ difference between the 2 measurements, a third $\mathrm{FEV}_{1}$ was performed. After the test, the higher of the two reproducible values was used to calculate the maximal decrease in $\mathrm{FEV}_{1}$. A post-EVH fall in $\mathrm{FEV}_{1}$ of at least $10 \%$ from baseline, sustained during at least 5-min or observable at two consecutive time-points was considered positive.

\section{Methacholine inhalation test (MIT)}

AHR to methacholine was measured using the tidalbreathing method described by Juniper et al. [17] After measurements of $\mathrm{FEV}_{1}$ and $\mathrm{FVC}$, subjects inhaled 0.9\% saline followed by doubling concentrations of methacholine, ranging from 0.03 to $128 \mathrm{mg} / \mathrm{ml}$, to obtain a $20 \%$ decrease in $\mathrm{FEV}_{1}$. Methacholine aerosols were generated from a Wright nebulizer with an output of $0.13 \mathrm{~mL} / \mathrm{min}$ and were inhaled for $2 \mathrm{~min}$ at $5 \mathrm{~min}$ intervals. $\mathrm{FEV}_{1}$ was measured at 30 and $90 \mathrm{~s}$ after each inhalation and every 2 min until it started to improve. An acceptable-quality $\mathrm{FEV}_{1}$ was obtained at each time point; otherwise the
$\mathrm{FEV}_{1}$ manoeuvre was repeated. AHR was defined as a $\mathrm{PC}_{20} \leq 4 \mathrm{mg} / \mathrm{mL}$, according to the World Anti-Doping Agency (WADA) and the International Olympic Committee's Medical Commission (IOC-MC) guidelines $[18,19]$. The impact of a methacholine challenge $\mathrm{PC}_{20}$ cut off $\leq 16 \mathrm{mg} / \mathrm{mL}$ on the prevalence of AHR was also studied.

\section{Induced sputum}

Induced sputum was obtained using hypertonic saline inhalation and processed according to the method described by Pin et al. [20] and modified by Pizzichini et al. [21] Increasing concentrations of saline $(3 \%, 4 \%$, and $5 \%$ ) were inhaled for $7 \mathrm{~min}$ each through a mouthpiece without a valve or nose clip. One cytospin slide was prepared, stained with Diff-Quik (DADE Diagnostics, Aguada, USA), and a 400 non-squamous cell differential was performed, including eosinophils, neutrophils, lymphocytes, macrophages, and bronchial epithelial cells.

\section{Statistical analysis}

Qualitative data are presented as percentages and quantitative data as mean \pm SD unless otherwise specified. Differences in proportions as well as continuous variables were compared using a conditional logistic regression statistical model. A Cox regression statistical approach was performed to analyse data. To analyse significant changes in the measured parameters between seasons, 4 experimental factors, 2 being matched for sets and subjects (random factors), 1 linked to the groups and the other linked to the serial measurements (the seasonal values) (fixed factors), were defined. The latter was analysed as a repeated-measure factor. The covariance structure used was an autoregressive one. The univariate normality assumption was verified with the Shapiro-Wilk test. The multivariate normality assumption was verified with the Shapiro-Wilk test after a Cholesky factorisation. The Brown and Forsythe's variation of Levene's test statistic was used to verify the homogeneity of variances. The Tukey's multiple comparison technique was applied posthoc to the ANOVA [22-24]. The results were considered statistically significant at a $\mathrm{p}$-value of $\leq 0.05$. The data were analysed using the statistical package program SAS v9.1.3 (SAS Institute Inc., Cary, NC).

\section{Results}

\section{Subjects' characteristics}

The subjects' characteristics are summarized in Table 1 . The mean age of subjects was $20 \pm 3$ years. The winter sports' athletes had been competing in long-track speed skating (19 skaters; outdoor ice rink), biathlon (9 biathletes), or cross-country skiing (25 skiers) for an average of $9 \pm 4$ years. They trained for a mean of $15 \pm 7 \mathrm{~h}$ per 
Table 1 Subjects' Characteristics

\begin{tabular}{llll}
\hline Variable & Athletes & Non-athlete subjects & $p$-value \\
\hline & $(n=53)$ & $(n=33)$ & \\
\hline Age (years) & $19 \pm 3$ & $21 \pm 3$ & 0.13 \\
\hline Ratio females to males & $19: 34$ & $15: 18$ & 0.74 \\
\hline Atopy (\%) & 67 & 67 & 0.45 \\
House dust & 47 & 42 & 0.81 \\
Animal & 36 & 42 & 0.62 \\
Tree pollen & 38 & 36 & 0.88 \\
$\quad$ Grass pollen & & & \\
\hline FEV 1 (\% predicted) & $115 \pm 13$ & $102 \pm 13$ & 0.21 \\
\hline FVC (\% predicted) & $125 \pm 13$ & $110 \pm 14$ & 0.38 \\
\hline FEV $/$ FVC (\%) & $94 \pm 7$ & $93 \pm 7$ & 0.54 \\
\hline $\mathrm{PC}_{20}$ (mg/ml) & $51.9[9.7-128]$ & $40.8[0.63-128]$ & 0.98 \\
\hline
\end{tabular}

Results are expressed as mean \pm SD unless otherwise noted

$\mathrm{FEV}_{1}$ : Forced expiratory volume in $1 \mathrm{~s}$

FVC: Forced vital capacity

${ }^{*} \mathrm{PC}_{20}$ : Concentration of inhaled methacholine causing a $20 \%$ decrease in the forced expiratory flow in $1 \mathrm{~s}$. Geometric mean [range]

week, including an average of $12 \pm 5 \mathrm{~h}$ per week outside. No differences were found between athlete and non-athlete subjects at baseline (summer) in terms of atopy, lung function, and airway responsiveness (AR). Thirty-one athletes completed the visit in summer, 37 in fall and 23 in winter. Many athletes did not attend the winter visit due to lack of time. Nineteen non-athlete subjects completed the visit in summer, 8 in fall, and 17 in winter.

\section{Cough symptoms}

In athletes, self-reported cough, $1 \mathrm{~h}$ following exercise (using the questionnaire) was more frequent in winter than summer ( $44 \%$ vs $71 \%, p=0.04$ ) (Table 2$)$. This

Table 2 Cough Symptoms at Exercise for each Season

\begin{tabular}{lllll}
\hline & Summer & Fall & Winter & $\begin{array}{l}{ }^{*} \boldsymbol{p} \text { - } \\
\text { value }\end{array}$ \\
\hline Athletes & $\mathbf{n = 3 1}$ & $\mathbf{n = 3 7}$ & $\mathbf{n}=\mathbf{2 3}$ & $\mathbf{0 . 4 5}$ \\
During exercise & $9 \%$ & $18 \%$ & $18 \%$ & $\mathbf{0 . 0 4 \dagger}$ \\
Within $1 \mathrm{~h}$ after exercise & $44 \%$ & $54 \%$ & $71 \%$ & 0.99 \\
Between 2 and $8 \mathrm{~h}$ after exercise & $24 \%$ & $21 \%$ & $21 \%$ & \\
\hline Non-athlete subjects & $\mathrm{n}=19$ & $\mathrm{n}=8$ & $\mathrm{n}=17$ & 0.99 \\
During exercise & $11 \%$ & $0 \%$ & $12 \%$ & 0.99 \\
Within $1 \mathrm{~h}$ after exercise & $16 \%$ & $3 \%$ & $18 \%$ & 0.47 \\
Between 2 and $8 \mathrm{~h}$ after exercise & $0 \%$ & $0 \%$ & $6 \%$ & \\
\hline ***-value & & & & \\
During exercise & 0.06 & 0.31 & 0.06 & \\
Within $1 \mathrm{~h}$ after exercise & 0.49 & $\mathbf{0 . 0 2}$ & 0.06 & \\
Between 2 and $8 \mathrm{~h}$ after exercise & 0.99 & 1.00 & 0.16 & \\
\hline
\end{tabular}

* p-value represent the within group comparisons

† Summer vs winter

** $p$-value represent the between group comparisons seasonal difference was not observed in the non-athlete group. During the fall, the prevalence of cough within the first hour after exercise was higher in athletes compared to non-athlete subjects $(54 \%$ vs $3 \%, p=0.02)$. There was a similar trend during winter $(71 \%$ vs $18 \%, p$ $=0.06$ ). Between 2 and $8 \mathrm{~h}$ after exercise, for all seasons, athletes reported late cough symptoms which were not reported in non-athlete subjects, but this difference was not statistically significant. As shown in Table 3, during summer, fall, and winter, both groups reported similar rates of cough symptoms under circumstances other than exercise. In both groups, there was no correlation between cough sensitivity to capsaicin and exerciseinduced cough either one hour after exercise or 2 to $8 \mathrm{~h}$ after exercise.

\section{Cough reflex sensitivity to capsaicin}

All subjects with a $C_{5}$ value of $1000 \mu \mathrm{M}$, were subjects who have not coughed five times. As shown in Figure 1, there were no changes in the cough reflex sensitivity to capsaicin through the seasons in either athletes or nonathlete subjects $(p=0.66)$. There were also no differences with this parameter between the 2 groups ( $p=$ 0.94) for each season. In athletes, mean $C_{5} \pm$ SD was 91 $\pm 4 \mu \mathrm{M}$ in summer, $68 \pm 4 \mu \mathrm{M}$ in fall and $42 \pm 5 \mu \mathrm{M}$ in winter. Female athletes had an increased cough reflex sensitivity to capsaicin compared to men athletes, during fall (34 $\pm 5 \mu \mathrm{M}$ vs $131 \pm 4 \mu \mathrm{M}$ respectively, $p=0.006)$. In non-athletes, mean $\mathrm{C}_{5} \pm \mathrm{SD}$ was $123 \pm 5 \mu \mathrm{M}$ in summer, $145 \pm 4 \mu \mathrm{M}$ in fall and $138 \pm 5 \mu \mathrm{M}$ in winter. No difference in cough reflex sensitivity to capsaicin was observed between genders in non-athlete subjects.

In both groups, no difference in cough reflex sensitivity to capsaicin was observed between subjects with or without AHR ( $\mathrm{p}>0.05)$. In athletes, no correlations were found between cough reflex sensitivity to capsaicin and the number of years of training in their sport (winter: $\mathrm{r}=0.20, p=0.37$ ), the number of hours training per week (winter: $\mathrm{r}=0.15, p=0.51$ ) and the number of hours training in cold air (winter: $\mathrm{r}=0.11, p=0.62$ ).

Furthermore, there were no significant correlations between cough reflex sensitivity to capsaicin and

Table 3 Cough Symptoms in Situations Other than Exercise

\begin{tabular}{lllll}
\hline & Summer & Fall & Winter & ${ }^{*} \mathbf{p}$-value \\
\hline Athletes & $\mathbf{n}=\mathbf{3 1}$ & $\mathbf{n}=\mathbf{3 7}$ & $\mathbf{n}=\mathbf{2 3}$ & $>\mathbf{0 . 9 9}$ \\
Other situations & $35 \%$ & $31 \%$ & $36 \%$ & \\
\hline Non-athlete subjects & $\mathrm{n}=19$ & $\mathrm{n}=8$ & $\mathrm{n}=17$ & 0.18 \\
Other situations & $37 \%$ & $66 \%$ & $65 \%$ & \\
\hline **p-value & 0.75 & 0.74 & 0.67 & \\
\hline * $p$-value represent the within group comparisons & & \\
** $p$-value represent the between group comparisons &
\end{tabular}




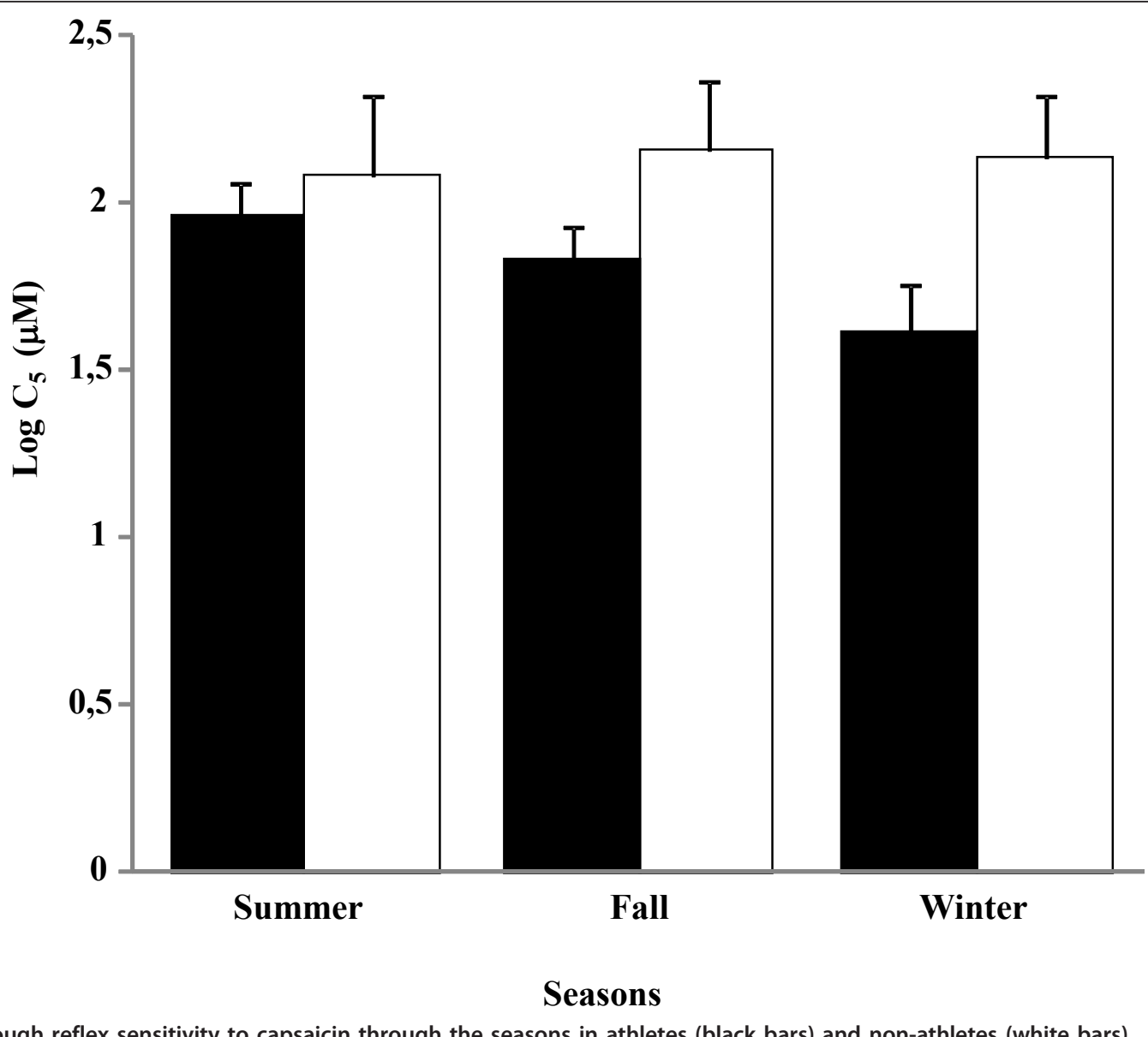

seasonal exposure to relevant allergens in sensitized subjects (data not shown). No correlations were found between airway responsiveness to methacholine $\left(\mathrm{PC}_{20}\right)$ and cough reflex sensitivity to capsaicin in athletes or in non-athlete subjects. No correlation was observed between the response to EVH (\% fall in $\mathrm{FEV}_{1}$ ) and cough reflex sensitivity to capsaicin in both groups (data not shown).

In both groups, subjects had mean sputum eosinophils and neutrophils within the normal range $(\leq 2 \%$ and $\leq$ $60 \%$, respectively). No correlations were found between cell counts in sputum and cough reflex sensitivity to capsaicin in non-athlete subjects or athletes (data not shown).

\section{Discussion}

To our knowledge, this is the first study to evaluate seasonal variations of cough reflex sensitivity to capsaicin in athletes. Athletes are known to frequently experience respiratory symptoms, cough being the most prevalent [2]. In our study, athletes had significantly more selfreported cough after exercise than non-athlete subjects, mostly within the first hour following exercise. Moreover, athletes also experienced cough 2 to $8 \mathrm{~h}$ after exercise, suggesting the presence of a late cough response. When analyzing all seasons together, athletes had $C_{5}$ values ranging from 42 to $91 \mu \mathrm{M}$ and non-athlete subjects had values between 123-144 $\mu \mathrm{M}$. Although the difference in cough reflex sensitivity to capsaicin is not statistically significant, athletes' $C_{5}$ values are lower than what is reported in the literature in healthy subjects $\left(C_{5}\right.$ : 125-186 $\mu \mathrm{M}$ ), while our non-athlete subjects were in the same range. In athletes, the cough reflex sensitivity to capsaicin is unlikely due to the amount of training, as no significant correlations were found between cough reflex sensitivity to capsaicin and the number of years of training or the number of hours of training per week.

It was also observed that athletes had a higher prevalence of cough, one hour post-exercise, in winter compared with summer. However, the cough reflex sensitivity to capsaicin was unchanged through the seasons in both athletes and non-athlete subjects. Therefore, this could not explain the increase in exerciseinduced cough during winter. 
Cough reflex sensitivity to capsaicin did not seem to be related to airway hyperresponsiveness or exerciseinduced bronchoconstriction, as there was no relationships found between cough reflex sensitivity to capsaicin and airway responsiveness to methacholine, atopy, response to EVH (\% fall in FEV1), or airway inflammation assessed by sputum. This may suggest that in athletes, cough is closely related to airway cough receptors' sensitivity to dehydration, possibly with an associated release of mediators. Cold air inhalation could induce neurogenic inflammation with release of tachykinins and kinins [25]. This is supported by our observation that some athletes experienced an increase in cough symptoms while at rest, 2 to $8 \mathrm{~h}$ following exercise. This suggests that in these subjects, exercise is the key factor inducing cough, but without changes in the cough reflex sensitivity to capsaicin. In this regard, intense training can induce the release of long-acting mediators such as leukotrienes, triggering cough receptors, but without a significant impact on cough reflex sensitivity to capsaicin. Thus there may be a dual early and late response pattern, such as the one observed after allergenic challenge or after physical exertion in children [26-28] and adult asthmatic subjects [38-41].

Exercise-induced bronchoconstriction has been shown to result from water loss; this might be true for cough as well $[29,30]$. It is conceivable that cough receptors may respond to thermal stimuli or to mediators that are produced or released as a consequence of airway cooling. Banner et al. [31] showed that hyperpnea with poorly conditioned air results in coughing, the frequency of which is directly related to the rate of respiratory heat loss. Hyperaemia occurs following the airway rewarming process and may lead to the activation of cough receptors by physical deformation of nerve ending. This could trigger cough receptors, despite not sufficiently to induce airway narrowing [32]. Respiratory water loss has tussive consequences by alteration of mucosal fluid osmolarity [33,34]. Water loss produces a hyperosmotic milieu in the bronchial mucosa that may alter the water-flux junctions between epithelial cells, leading to the discharge of nerve receptors lying close to these junctions [35]. Further supporting this possibility is the observation that hypertonic aerosols such as saline or mannitol have tussive effects in humans. If respiratory water loss is indeed a tussive stimulus, high rates of water loss would lead to coughing when cough reflex sensitivity is increased. Exercise-induced cough may result by a mechanism related to hyperpnea. Forced manoeuvres may cause cough, by deformation of airway receptors. Lung distortion or stretching may also release prostaglandins which have been shown to provoke cough by discharge of airway C-fibers [36,37]. However, the precise mechanism of cough without bronchoconstriction during cold air inhalation is unclear. In our study, cooling-induced cough was not associated with exercise-induced bronchoconstriction. This is in keeping with other authors who observed that exercise-induced bronchoconstriction may be prevented by a beta-2-agonist without affecting cough [32].

Contrary to our hypothesis, cold-air athletes did not have a significant increased cough reflex sensitivity to capsaicin. One possible explanation for these findings is that capsaicin challenge was perhaps not the appropriate test to assess cough reflex sensitivity in this population. It is possible that in cold-air athletes, cough receptors could be damaged. Long-term exposure to cold and dry air may desensitize the cough receptors residing within the airway epithelium and could make them less sensitive to capsaicin. This could explain why we observed a high prevalence of symptoms in athletes without an increase in cough reflex sensitivity to capsaicin. Alternatively, inhalation of cold and dry air may induce changes in the airway mucus and modulate cough reflex sensitivity. Enhanced mucus volume may provide a barrier shielding the superficial airway cough receptors from tussive stimuli of capsaicin, inducing an inhibition of Cfibers or the depletion of neuropeptides. This could possibly explain the diminished sensitivity to capsaicin $[25,26]$.

Interestingly, Xing et al. [27] have shown that a subpopulation of vagal afferent neurons innervating bronchopulmonary tissues expresse TRPM8 receptors and that these receptors could be excited by cold. These findings provide a possible molecular mechanism by which cold induces autonomic responses in the respiratory system. Thus, TRPM8 receptors have functions beyond encoding for consciousness of cold sensation in somatic sensory system. Temperature in the upper airway, such as the laryngeal tracheal region, may be below $25^{\circ} \mathrm{C}$ in a cold air environment. It is possible that TRPM8 receptors are mainly expressed in upper airway trees, where the receptors serve as a cold temperature sensor to mediate reflexive responses.

\section{Limitations}

One limitation of this study is that we have not formerly assessed the presence or absence of other potential causes of cough such as gastro-oesophageal reflux and rhinitis. Also, not all subjects completed the three visits. Consequently, the small and variable sample size possibly resulted in a lack of statistical power. In the present study, a global analysis of the data, considering missing data within the framework of the analysis was used. We understand that this can underestimate possible changes but we believe that it provides useful data on such potential variations. 


\section{Conclusion}

High occurrence of cough symptoms was observed in athletes during cold-air training. However, this process does not have a significant impact on the cough reflex's sensitivity to capsaicin and is usually not associated with bronchoconstriction, airway hyperresponsiveness, or airway inflammation in the majority of athletes. As this cough often poorly responds to treatment [28,38], research should be done to address this troublesome symptom in winter athletes.

\section{Abbreviations \\ AR: airway responsiveness; AHR: airway hyperresponsiveness; $\mathrm{CO}_{2}$ : carbon dioxide; EIB: exercise-induced bronchoconstriction; EVH: eucapnic voluntary hyperpnoea; $\mathrm{FEV}_{1}$ : forced expiratory volume in one second; FVC: forced vital capacity; IOC-MC: International Olympic Committee's Medical Commission; MIT: methacholine inhalation test; $\mathrm{PC}_{20}$ : concentration of inhaled methacholine causing a $20 \%$ decrease in the forced expiratory volume in 1 s; WADA: World Anti-Doping Agency}

\section{Acknowledgements}

We thank the Conseil des Sports de Haut Niveau de Québec (CSHNQ) for their support, Lynn Atton for the technical assistance, and Serge Simard for his help with the statistical analysis.

\section{Author details}

${ }^{1}$ Centre de recherche de I'Institut universitaire de cardiologie et de Pneumologie de Québec, 2725 Chemin Ste-Foy, Québec, Qc G1V 4G5, Canada. ${ }^{2}$ Université du Droit et de la Santé, Faculté des Sciences du Sport et de l'Éducation physique, 9 rue de l'Université, Ronchin 59790, France.

\section{Authors' contributions}

JT (1) conception and design of the study; (2) data generation; (3) analysis and interpretation of the data and (4) preparation of the manuscript. VB (1) data generation; (2) analysis and interpretation of the data and (3) critical revision of the manuscript. LPB (1) conception and design of the study; (3) interpretation of the data and (4) preparation or critical revision of the manuscript. All authors read and approved the final version of the manuscript.

\section{Competing interests}

The authors declare that they have no competing interests.

Received: 5 December 2011 Accepted: 26 March 2012 Published: 26 March 2012

\section{References}

1. Bateman ED, Hurd SS, Barnes PJ, Bousquet J, Drazen JM, FitzGerald M, Gibson P, Ohta K, O'Byrne P, Pedersen SE, Pizzichini E, Sullivan SD, Wenzel SE, Zar HJ: Global strategy for asthma management and prevention: GINA executive summary. Eur Respir J 2008, 31(1):143-178.

2. Rundell KW, Im JH, Mayers LB, Wilber RL, Szmedra L, Schmitz HR: Selfreported symptoms and exercise-induced asthma in the elite athlete. Medicine and Science in Sports and Exercise 2001, 33(2):208-213.

3. Heir T, Oseid S: Self-reported asthma and exercise-induced asthma symptoms in high-level competitive cross-country skiers. Scandinavian Journal of Medicine and Science in Sports 1994, 4:128-133.

4. McFadden ER, Pichurko BM, Bowman HF, Ingenito E, Burns S, Dowling N, Solway J: Thermal Mapping of the Airways in Humans. Journal of Applied Physiology 1985, 58(2):564-570.

5. Ingenito EP, Solway J, McFadden ER, Pichurko B, Bowman HF, Michaels D, Drazen JM: Indirect Assessment of Mucosal Surface Temperatures in the Airways - Theory and Tests. J Appl Physiol 1987, 63(5):2075-2083.

6. O'Connell F, Thomas VE, Studham JM, Pride NB, Fuller RW: Capsaicin cough sensitivity increases during upper respiratory infection. Respiratory Medicine 1996, 90(5):279-286.
7. Doherty MJ, Mister R, Pearson MG, Calverley PMA: Capsaicin responsiveness and cough in asthma and chronic obstructive pulmonary disease. Thorax 2000, 55(8):643-649.

8. Widdicombe JG: Neurophysiology of the Cough Reflex. European Respiratory Journal 1995, 8(7):1193-1202.

9. Midgren B, Hansson L, Karlsson JA, Simonsson BG, Persson CGA: CapsaicinInduced Cough in Humans. American Review of Respiratory Disease 1992, 146(2):347-351.

10. Nieto L, de Diego A, Perpina $M$, Compte L, Garrigues V, Martinez E, Ponce J: Cough reflex testing with inhaled capsaicin in the study of chronic cough. Respiratory Medicine 2003, 97(4):393-400.

11. Prudon B, Birring SS, Vara DD, Hall AP, Thompson JP, Pavord ID: Cough and glottis-stop reflex sensitivity in health and disease. Chest 2005, 127(2):550-557.

12. Miller MR, Hankinson J, Brusasco V, Burgos F, Casaburi R, Coates A, Crapo R, Enright P, van der Grinten CPM, Gustafsson P, Jensen R, Johnson DC, Maclntyre N, Mckay R, Navajas D, Pedersen OF, Pellegrino R, Viegi G, Wanger J: Standardisation of spirometry. European Respiratory Journal 2005, 26(2):319-338.

13. Mahler DA: Exercise-Induced Asthma. Medicine and Science in Sports and Exercise 1993, 25(5):554-561

14. Gardner RM: Standardization of Spirometry - A Summary of Recommendations from the American Thoracic Society - the 1987 Update. Ann Intern Med 1988, 108(2):217-220.

15. Knudson RJ, Lebowitz MD, Holberg CJ, Burrows B: Changes in the Normal Maximal Expiratory Flow-Volume Curve with Growth and Aging. Am Rev Respir Dis 1983, 127(6):725-734.

16. Anderson SD, Brannan JD: Methods for "indirect" challenge tests including exercise, eucapnic voluntary hyperpnea, and hypertonic aerosols. Clin Rev Allergy Immunol 2003, 24(1):27-54.

17. Juniper EF, Cockcroft DW, Kolendowicz R: Histamine and methacholine inhalation tests: tidal breathing method;laboratory procedure and standardization. Astra Draco AB 1994

18. International Standards. List of Prohibited Substances and Methods World Anti-Doping Agency (WADA). [http://www.wadaama.org/ Documents/Science_Medicine/Medical_info_to_support_TUECs/ WADA_Medical_info_Asthma_V3_EN.0.pdf].

19. Beta2 adrenoceptor agonists and the Olympic Games in Beijing International Olympic Committee. The Medical Comission (IOC-MC) [http://multimedia.olympic.org/pdf/en_report_1302.pdf].

20. Pin I, Gibson PG, Kolendowicz R, Girgisgabardo A, Denburg JA, Hargreave FE, Dolovich J: Use of Induced Sputum Cell Counts to Investigate Airway Inflammation in Asthma. Thorax 1992, 47(1):25-29.

21. Pizzichini E, Pizzichini MMM, Efthimiadis A, Evans S, Morris MM, Squillace D, Gleich GJ, Dolovich J, Hargreave FE: Indices of airway inflammation in induced sputum: Reproducibility and validity of cell and fluid-phase measurements. Am J Respir Crit Care Med 1996, 154(2):308-317.

22. Siddiqui $\mathrm{O}: \mathrm{A}$ comparision of the random-effects pattern mixture model with lastobservation-carried-foward (LOCF) analysis in longitudinal clinical trails with dropouts. J Biopharm Stat 1998, 8(4):545-563.

23. Mallinckrodt CH CWDSR: Accounting for dropout bias using mixed-effects models. J Biopharm Stat 2001, 11(1-2):9-21.

24. Gadbury GL, Coffey CS, Allsion DB: Modern statistical methods for handling missing repeated measurements in obesity trial data: beyond LOCF. Obesity Reviews 2003, 4(3):175-184.

25. Millqvist $\mathrm{E}$, Bende $\mathrm{M}$ : Capsaicin cough sensitivity is decreased in smokers. Respir Med 2001, 95(1):19-21.

26. Rubin BK, Ramirez O, Zayas JG, Finegan B, King M: Respiratory Mucus from Asymptomatic Smokers Is Better Hydrated and More Easily Cleared by Mucociliary Action. Am Rev Respir Dis 1992, 145(3):545-547.

27. Xing $H$, Ling JX, Chen $M$, Johnson RD, Tominaga M, Wang CY, Gu JG: TRPM8 mechanism of autonomic nerve response to cold in respiratory airway. Mol Pain 2008, 4:22

28. Helenius I, Lumme A, Ounap J, Obase Y, Rytila P, Sarna S, Alaranta A, Remes $V$, Haahtela T: No effect of montelukast on asthma-like symptoms in elite ice hockey players. Allergy 2004, 59(1):39-44.

29. Anderson SD, Schoeffel RE, Follet R, Perry CP, Daviskas E, Kendall M: Sensitivity to Heat and Water-Loss at Rest and During Exercise in Asthmatic-Patients. European Journal of Respiratory Diseases 1982, 63(5):459-471 
30. Deal EC, McFadden ER, Ingram RH, Strauss RH, Jaeger JJ: Role of Respiratory Heat-Exchange in Production of Exercise-Induced Asthma. Appl Physiol 1979, 46(3):467-475.

31. Banner AS, Green J, Oconnor M: Relation of Respiratory Water-Loss to Coughing After Exercise. New England Journal of Medicine 1984, 311(14):883-886.

32. Banner AS, Chausow A, Green J: The Tussive Effect of Hyperpnea with Cold Air. American Review of Respiratory Disease 1985, 131(3):362-367.

33. Sheppard D, Rizk NW, Boushey HA, Bethel RA: Mechanism of Cough and Bronchoconstriction Induced by Distilled Water Aerosol. Am Rev Respir Dis 1983, 127(6):691-694.

34. Eschenbacher WL, Boushey HA, Sheppard D: Alteration in Osmolarity of Inhaled Aerosols Cause Bronchoconstriction and Cough, But Absence of A Permeant Anion Causes Cough Alone. Am Rev Respir Dis 1984, 129(2):211-215.

35. Hogg JC, Eggleston PA: Is Asthma An Epithelial Disease. American Review of Respiratory Disease 1984, 129(2):207-208.

36. Piper PJ, Vane JR: The release of prostaglandins from lung and other tissues. Ann NY Acad Sci 1971, 180:363-365.

37. Coleridge HM, Coleridge JCG, Ginzel KN, Baker DG, Banzett RB, Morrison MA: Stimulation of irritant receptors and afferent C-fibers in the lungs by prostaglandins. Nature 1976, 264:451-452.

38. Sue-Chu M, Karjalainen EM, Laitinen A, Larsson L, Laitinen LA, Bjermer L: Placebo-controlled study of inhaled budesonide on indices of airway inflammation in bronchoalveolar lavage fluid and bronchial biopsies in cross-country skiers. Respiration 2000, 67(4):417-425.

doi:10.1186/1745-9974-8-2

Cite this article as: Turmel et al: Seasonal variations of cough reflex sensitivity in elite athletes training in cold air environment. Cough 2012 8:2.

\section{Submit your next manuscript to BioMed Central} and take full advantage of:

- Convenient online submission

- Thorough peer review

- No space constraints or color figure charges

- Immediate publication on acceptance

- Inclusion in PubMed, CAS, Scopus and Google Scholar

- Research which is freely available for redistribution

Submit your manuscript at www.biomedcentral.com/submit
Biomed Central 